\title{
Determinants of satisfaction amongst tenants of UK Offices
}

Article

Accepted Version

Sanderson, D. C. and Edwards, V. M. (2016) Determinants of satisfaction amongst tenants of UK Offices. Journal of Corporate Real Estate, 18 (2). pp. 102-131. ISSN 1463-001X doi: https://doi.org/10.1108/JCRE-09-2015-0022 Available at https://centaur.reading.ac.uk/51460/

It is advisable to refer to the publisher's version if you intend to cite from the work. See Guidance on citing.

To link to this article DOI: http://dx.doi.org/10.1108/JCRE-09-2015-0022

Publisher: Emerald Publications Ltd

All outputs in CentAUR are protected by Intellectual Property Rights law, including copyright law. Copyright and IPR is retained by the creators or other copyright holders. Terms and conditions for use of this material are defined in the End User Agreement.

\section{www.reading.ac.uk/centaur}

\section{CentAUR}

Central Archive at the University of Reading

Reading's research outputs online 


\title{
Determinants of satisfaction amongst Tenants of UK Offices
}

\author{
Abstract \\ Purpose - Corporate Occupiers require offices and services which meet their business needs, whilst \\ landlords must attract and retain occupiers in order to maximise occupancy and rental income. The purpose \\ of this research is to help landlords and corporate occupiers understand each other better, in order to achieve \\ a mutually beneficial relationship.
}

Design/methodology/approach - This paper analyses interviews with 1334 office tenants in the UK, conducted over an 11-year period, to investigate determinants of occupier satisfaction, loyalty and advocacy. Structural equation modelling and regressions are performed using respondents' ratings of satisfaction with many aspects of occupancy as explanatory variables. The dependent variables include satisfaction with property management, value for money, overall occupier satisfaction, lease renewal intentions and occupiers' willingness to recommend their landlord.

Findings - The aspects with most impact on occupiers' satisfaction are the office building itself, its location and amenities, and also communication with their property manager, a belief that their business needs are understood and the property manager's responsiveness to occupiers' requests. Occupiers' loyalty depends mainly upon feeling that their rent and service charges provide value for money, an amicable leasing process, the professionalism of their property manager and the Corporate Social Responsibility of the Landlord. 'Empathy' is crucial to occupiers' willingness to recommend their landlord, and clear documentation and efficient legal process improve occupiers' perception of receiving 'Value for Money'.

Research Limitations - The sample is skewed towards occupiers of prime office buildings in the UK, owned by landlords who care sufficiently about their tenants to commission studies into occupier satisfaction.

Practical implications - This research should help to improve the landlord - tenant relationship, benefitting the businesses that rent property and helping building managers understand where to focus their efforts to achieve maximum effect on occupier satisfaction, loyalty and advocacy.

Originality/value - There has been little academic research into the determinants of satisfaction of occupiers of UK commercial property. This large-scale study enables the most influential factors to be identified and prioritised. 


\section{Introduction}

Customer Relationship Management (CRM) theory is based upon the premise that good customer service results in satisfied customers, who in turn are more likely to remain loyal and recommend the service provider to others (Keiningham et al., 1999; Keiningham, Perkins-Munn, \& Evans, 2003; Rust, Zahorik, \& Keiningham, 1994; Söderlund \& Vilgon, 1999). This concept is known as the "service-profit chain" (Heskett, Sasser, \& Schlesinger, 1997). Applied to commercial property management, the theory implies tenants should receive better service whilst landlords should achieve a return on investment in delivering that service, in the form of increased lease renewal rates and an improvement in the reputation of the landlord and the property manager who acts on their behalf, resulting in fewer void periods without compromising rents.

Traditionally there has been a somewhat adversarial relationship between landlords and tenants. Adam Smith (1776 p. 124) believed that rent had a "natural" level, which would maximise the benefit to the landlord, with lease terms being set so as to give the tenant the smallest viable tract of land for the maximum price the tenant could afford to pay. Until the late $20^{\text {th }}$ century, property management continued to be about maximising rents and rapid recourse to legal process to resolve disputes between landlord and tenant. Edington (1997 p. xii) points out that the traditional approach to property management "gives no glimpse of the notion that if a supplier (the landlord) is receiving substantial sums (rents) from the customer (tenant), then the customer has the right to receive exemplary service." Edington was an early proponent of the need for customer-focused property management, eschewing the "old way" of treating customers as a source of "upwardly mobile income" and recognizing instead that "it is the tenants that are mobile and that their custom must be earned."

Other real estate practitioners and writers have recognised that historically the real estate industry has not focused enough on customer relationships (Silver, 2000; Valley, 2001; Worthington, 2015). During the past decade there has been a gradual shift in attitude and behaviour on the part of property owners and managing agents towards a more customer-oriented approach to property management. The RealService Best Practice Group was founded in 2004 as a benchmarking and best practice group of property owners and managers "dedicated to helping the real estate industry improve customer service and generate improved property performance" (Morgan; RealService Ltd, 2010).

This research is based upon an analysis of 1334 interviews with corporate occupiers of UK offices, conducted between 2003 and 2014 by RealService consultants on behalf of landlords. Clients commissioning these studies include many of the property companies - Real Estate Investment Trusts (REITs) and Real Estate Operating Companies (REOCs) - with the largest commercial portfolios. The purpose of this research is to improve understanding between landlords and their tenants, to help landlords and the property managers who act on their behalf to understand what aspects of property management matter most to occupiers, and to identify where there is greatest scope for improving occupier satisfaction and loyalty. In particular, the research addresses the following questions: 


\section{Research Questions}

This research aims to improve the mutual understanding between landlords and corporate occupiers, by addressing the following questions:

- Question 1: What do corporate occupiers consider to be the characteristics of the ideal landlord?

- Question 2: What are the determinants of occupier satisfaction?

- Question 3: What are the determinants of occupier loyalty

- Question 4: What are the determinants of landlord reputation and occupiers' willingness to recommend their landlord or property manager?

\section{Review of Previous Research}

It is not possible to measure Property Management Service Quality directly, because quality is in the "eye of the beholder". Rather, quality has to be inferred from the recipient's assessment. However, the recipients are not homogeneous, the service itself is not necessarily consistent, and opinions differ. The characteristics of SERVICE are widely acknowledged to include "intangibility, relative inseparability of production and consumption, and relative heterogeneity by virtue of involving the interaction of service personnel and customers, making each instance of service different" (Schneider \& White, 2004, p. 8).

Many researchers have attempted to assess, define and model quality in service encounters, including Grönroos (1978, 1982, 1990); Gummesson (2002a, 2002b); Kano et al., (1984); P. Nelson (1974); and Yang (2005) Perhaps the most widely known model of service quality is SERVQUAL (Parasuraman, Zeithaml, \& Berry, 1985, 1988; Zeithaml, Berry, \& Parasuraman, 1990, 1996), which is based upon gaps between the service expected and the service experienced. The original model included ten determinants of service quality: Access, Communication, Competence, Courtesy, Credibility, Reliability, Responsiveness, Security, Tangibles and Understanding (Parasuraman et al., 1985). These were later condensed into five dimensions: 'Tangibles', 'Reliability', 'Responsiveness', 'Assurance', and 'Empathy' (Parasuraman et al., 1988).

Variants of SERVQUAL have been devised for real estate service quality measurement. RESERV is a model designed to measure satisfaction with Residential Real Estate Brokerage agent (Nelson \& Nelson, 1995). It uses the five dimensions of SERVQUAL plus an additional two: Professionalism and Availability. The professionalism of the lettings agent has been shown to be a good predictor of a customer's likelihood to recommend a real estate broker (Seiler \& Reisenwitz, 2010; Seiler, Webb, \& Whipple, 2000), and is an important factor for prospective corporate occupiers as it gives a first impression of the service which they might expect to receive. Owners who are entrusting the task of acquiring occupiers to agents must ensure that appropriate incentives and key performance indicators are in place to ensure they deliver a professional service (Ronco, 1998; Williamson, 2002). 
Johnson, Dotson, \& Dunlap (1988) found that the determinants of real estate service quality conform to those of Parasuraman, Zeithaml, \& Berry (1985) but differ in order of importance, and consist of: service assurances and responsiveness, tangible firm characteristics, tangible product characteristics, reliability of service, and service empathy. SERVPERF is a variant of SERVQUAL which focuses on perception of performance, without the need to measure expectations (Cronin Jr \& Taylor, 1992), an approach endorsed by Seiler et al., (2010) who found that, when measuring the likelihood of customers recommending a broker, "in real estate, it is better not to incorporate expectations into the [measurement] scale"(p. 59), because "it is not clear whether [respondents] answer based on their initial expectations (which are largely contaminated by their overall satisfaction)” (p.60). Other dimensions used in research by Westbrook \& Peterson (1998) and Van Ree (2009) include Credibility, Security, Competence, Accessibility, Communication, Understanding, Courtesy, Consulting, Offering, Clout, Geographics and Price. The inclusion of Price as one of the dimensions allows an explicit assessment of the extent to which value for money affects responses. Van Ree's analysis of office cleaning, catering and security services found all of the service quality dimensions apart from 'Clout' (influence or market share) to be strongly or moderately related to customer perceived service quality and customer satisfaction.

PROPERTYQUAL is a model designed to investigate occupier satisfaction with purpose-built office buildings, and uses SERVQUAL's five dimensions plus some property-specific ones: Cleanliness, Building services, Signage, Security, Parking and Building aesthetics (Baharum, Nawawi, \& Saat, 2009). Based on responses from occupiers of 318 office buildings, the researchers found that occupiers believe cleanliness, security and building services to be the most important property-specific aspects of property management. From a service perspective, reliability and responsiveness were found to be of most importance to occupiers.

According to Wilson et al., (2001), the customers of corporate real estate organisations value responsiveness and flexibility, an understanding of their customers' needs and accountabilities, professionalism, reliability, accessibility, risk management, ease of doing business and competitive pricing / value-for-money / affordability. Chin \& Poh (1999) discuss the application of Total Quality Management (TQM) to property management, stating that "customer satisfaction in property management means providing professional, reliable and consistent delivery of management services to the client ... [ensuring that the properties they manage are] in satisfactory working order at all times, with minimal breakdowns and disruptions."

Aspects of property management which "keep, push or pull" office occupiers have been assessed for their impact on satisfaction and loyalty (Appel-Meulenbroek, 2008). Most of the factors relate to physical aspects of the property or its hinterland, but the paper emphasises the need for CRM processes "to keep satisfaction at such a level that it invokes loyalty" and increases 'retention equity'. "Keep Factors" were found to include building services, scope to extend, flexibility and locational factors that would generally have been considered when choosing the property initially, such as 
proximity to a city, accessibility and availability of parking. "Push factors" are those which encourage defection, whereas pull factors are those which result from a competitor attracting a customer away from the original supplier. Push and pull factors were found to relate to building maintenance, the quality of fittings, internal climate and the appearance of the building, so Appel-Meulenbroek advises that a landlord should endeavour to keep buildings up-to-date.

In their study into switching behaviour and loyalty to property service suppliers, Levy \& Lee (2009) categorised the main reasons for switching suppliers as: core service failure, external requirements, relationships, change in client's requirements, attraction by competitors and pricing. In switching suppliers ('defecting'), there are various costs: procedural, financial \& relational (Gee, Coates, \& Nicholson, 2008). For occupiers of commercial property, the main barriers to switching relate to the costs and amount of upheaval involved, so the decision not to renew a lease will not be made lightly, but however excellent the service quality and however satisfied the customer, there will always be some "customer defections" (Venkateswaran, 2003). Occupiers' businesses may fail, large corporations may decide to rationalise their use of space or need to relocate for other commercial reasons, and the cost of renting the premises may be deemed too high; indeed a global occupier satisfaction study conducted by BOMA \& Kingsley Associates (2013) found that occupiers' greatest concern was their rent and the total overall costs of occupation.

For services that are included in the rent and service charge, occupiers require a "well-drafted service level agreement with a provider they can trust" (Gibson et al., 2000), and want to feel confident that service charges are fair, transparent and well-managed (Freethy, Morgan, \& Sanderson, 2011; Noor et al.,, 2010; Noor \& Pitt, 2009; Tucker \& Pitt, 2010). Giving occupiers good value for money requires attention to be paid to the full service-delivery process rather than optimising sub-processes, good communication and ensuring property managers behave professionally and feel valued (Jylha \& Junnila, 2014; Sanderson, 2012).

In the UK, the Real Service Best Practice Group defines best practice in property ownership and management using a framework which encompasses Service strategy, Customer Solutions, People and Leadership, Supply Chain Management, Operations and Measurement. The Property Industry Alliance and CORENET GLOBAL UK carried out annual surveys between 2007 and 2013 to assess the satisfaction of occupiers of UK Commercial Property ("UK Occupier Satisfaction Index 2007-2012," 2012). Table 1 summarises key findings from these studies, together with findings from an earlier, smaller study. The perennial dissatisfaction with value for money for service charges is clear, although satisfaction with lease flexibility appears to have improved over the years, as lease durations in the UK have decreased (Frodsham, 2010; IPD, Strutt \& Parker, \& BPF, 2012, 2013). 
Table 1: Summary of Findings from UK Occupier Satisfaction Studies (table compiled by author using data from http://www.occupiersatisfaction.org.uk/)

\begin{tabular}{|c|c|c|c|}
\hline Year of Study & Respondents & OSI Score ${ }^{1}$ & Key Findings \\
\hline $\begin{array}{l}2004-5 \\
\text { (IPD, Cfi-group, \& RICS, } \\
2005)\end{array}$ & 85 & $39 / 100$ & $\begin{array}{l}\text { - Satisfaction with location and standard of premises - High; } \\
\text { - Satisfaction with lease flexibility, communication with } \\
\text { landlord / agent, responsiveness, contract detail, problem } \\
\text { resolution and value for money - Low. }\end{array}$ \\
\hline $\begin{array}{l}2006-7 \\
\text { (KingsleyLipseyMorgan } \\
\text { \& IPD Occupiers, 2007) }\end{array}$ & 237 & $55 / 100$ & $\begin{array}{l}\text { - Leases perceived to be more flexible and better suited to } \\
\text { business needs, but perhaps at too high a price; } \\
\text { Occupiers did not feel 'valued customers' and wanted } \\
\text { property owners to show a greater understanding of their } \\
\text { needs; } \\
\text { Respondents wanted more direct contact with their } \\
\text { landlord. }\end{array}$ \\
\hline $\begin{array}{l}\text { 2007-8 } \\
\text { (KingsleyLipseyMorgan } \\
\text { \& IPD Occupiers, 2008) }\end{array}$ & 251 & $57 / 100$ & $\begin{array}{l}\text { - Fewer respondents gave ratings of 'poor' or 'very poor' } \\
\text { compared with } 2006 / 7 \text {; } \\
\text { - Highest level of dissatisfaction was with value for money } \\
\text { for service charges; } \\
\text { - Larger organisations showed higher levels of satisfaction. }\end{array}$ \\
\hline $\begin{array}{l}2008-9 \\
\text { (RealService Ltd \& IPD, } \\
\text { 2009) }\end{array}$ & 231 & $57 / 100$ & $\begin{array}{l}\text { - Satisfaction with lease flexibility, sustainability, and } \\
\text { landlord - tenant relationships appeared to be improving; } \\
\text { Occupiers' main priority was cost control, and half of } \\
\text { respondents felt service charges were poor value and } \\
\text { documentation about expenditure insufficiently } \\
\text { transparent. }\end{array}$ \\
\hline $\begin{array}{l}2010 \\
\text { (Property Industry } \\
\text { Alliance \& Corenet } \\
\text { Global, 2010) }\end{array}$ & 163 & $4.9 / 10$ & $\begin{array}{l}\text { - Satisfaction highest for processes of rent review, leasing, } \\
\text { and handing back of property; } \\
\text { Lowest satisfaction for service charge arrangements, } \\
\text { environmental initiatives and obtaining applications for } \\
\text { consent }\end{array}$ \\
\hline $\begin{array}{l}2011 \\
\text { (GVA, Property } \\
\text { Industry Alliance, \& } \\
\text { Corenet Global, 2011) }\end{array}$ & 159 & $5.4 / 10$ & $\begin{array}{l}\text { - Satisfaction with the rent review process had deteriorated } \\
\text { compared with the previous year, although satisfaction } \\
\text { with the leasing process and the terms and conditions } \\
\text { achieved was reasonably high; } \\
\text { - The aspects with lowest satisfaction were service charge } \\
\text { arrangements and landlord interaction on environmental } \\
\text { issues. }\end{array}$ \\
\hline $\begin{array}{l}2012 \\
\text { (Property Industry } \\
\text { Alliance \& GVA, 2012) }\end{array}$ & 182 & $5.1 / 10$ & $\begin{array}{l}\text { - Negotiation of dilapidations was considered } \\
\text { unsatisfactory, particularly by respondents from small and } \\
\text { medium enterprises; } \\
\text { - Although satisfaction with service charge arrangements } \\
\text { had improved, it was still low, at } 4.7 / 10 \text {. }\end{array}$ \\
\hline
\end{tabular}

Attempts to conduct UK Occupier Satisfaction studies in 2013 and 2014 were unsuccessful because the on-line questionnaire attracted too few responses to make meaningful analysis possible. However a recent study into the opinions of major corporate occupiers conducted on behalf of the British Council for Offices (British Council for Offices \& RealService Ltd, 2015) compared the satisfaction of office occupiers in 2015 with those of a similar study conducted in 2002 (British Council for Offices \& KingsleyLipseyMorgan, 2002). The 2002 Study found that "The UK office industry is failing to meet

\footnotetext{
${ }^{1}$ Note three different methodologies were employed to calculate the "occupier satisfaction index" for 2005, 2007-9, and 2010-12
} 
the levels of service demanded by its customers", and that "UK occupiers remain frustrated by the adversarial nature of the property industry" (p. 5). One UK property director expressed the opinion that: "The attitude of landlords is 'you are lucky to be talking to us!' I don't expect to have to fight for a relationship when I buy a service," (p. 8). In the recent study, satisfaction with aspects such as lease flexibility, understanding of occupiers' needs, and amenities within the office and the vicinity had improved markedly since the earlier study, and the property industry was perceived to be less adversarial.

As part of the research, a series of focus groups was held, and participants derived a proposed definition of "Building Performance":

“Building performance can be defined as the way that a building supports occupiers' differing aims and needs, including driving quality and value, meeting sustainability objectives and providing environments that meet the needs of users, resulting in efficient and effective workplaces" (p. 32).

The research also suggested creating a scorecard to measure building performance, aiming to achieve that "sweet spot" (p. 29) that balances the needs of landlords, property managers and occupiers. Satisfaction with value for money was found to have increased between the two studies, and the researchers state that "occupiers consistently place value and quality ahead of cost considerations when defining building performance" (p. 29). The authors suggest that finding ways to "enhance the occupiers' business profitability" may be more important than "seek[ing] to reduce operating costs (e.g. service charges)". This idea is supported by Coenen, Alexander, \& Kok, (2012, p. 83), who propose that Facilities Management can contribute "Use Value”, "Social Value”, "Environmental Value”, and "Relationship Value" to an organisation.

Occupier satisfaction studies have taken place in other parts of the world too. The 2002 study into Office Occupier Satisfaction referred to earlier (British Council for Offices \& KingsleyLipseyMorgan, 2002) also interviewed property directors in the United States. Whereas in the UK the relationship with landlords was perceived to be confrontational and hierarchical, occupiers in the U.S. were more satisfied with the relationship with their landlords, and felt they were treated as valued customers. The importance of property management was highlighted, too, in a very recent study into occupier satisfaction in both the Netherlands and the UK (CBRE, 2015), which found that "effective and efficient property management has a clear bearing on occupier satisfaction”.

A Global Tenant Survey was conducted in 2013 (BOMA \& Kingsley Associates, 2013), and covered the United States, Canada, New Zealand and South Africa. 1200 occupiers of predominantly office buildings responded to the survey. Occupier satisfaction was found to be highest in the United States (4.09 / 5) and lowest in South Africa (3.43 / 5). The study found that tenants occupying the largest amount of space had higher overall satisfaction, supporting the findings of the UK OSI studies (KingsleyLipseyMorgan \& IPD Occupiers, 2008), and other research that has demonstrated that larger organisations have higher levels of satisfaction, apparently as a result of obtaining better terms because of their clout (Crosby et al., 2006b; Halvitigala, Murphy, \& Levy, 2011). Interestingly, this 
view is not supported by the recent study into the satisfaction of office occupiers in the UK (British Council for Offices \& RealService Ltd, 2015) in which respondents felt that "it is not the case that the big occupiers are getting the best service and smaller occupiers are losing out” (p. 16). Rather, receiving good service can be a "complete lottery".

Figure 1 shows average satisfaction with aspects of property management in the last three of the UK Occupier Satisfaction Studies. It can be seen that levels of satisfaction remained broadly stable over these years, at around 5 on a 10-point scale for most aspects. The change in the way that satisfaction was assessed means that direct comparisons of these aspects with earlier years is not possible. One inference that can be drawn from the graph is the disparity between the importance of sustainability to corporate occupiers and their satisfaction with the interaction with landlords on environmental issues.

Figure 1: UK Occupier Satisfaction Index: 2010 - 2012 (graph compiled by the author using data from http://www.occupiersatisfaction.org.uk/)

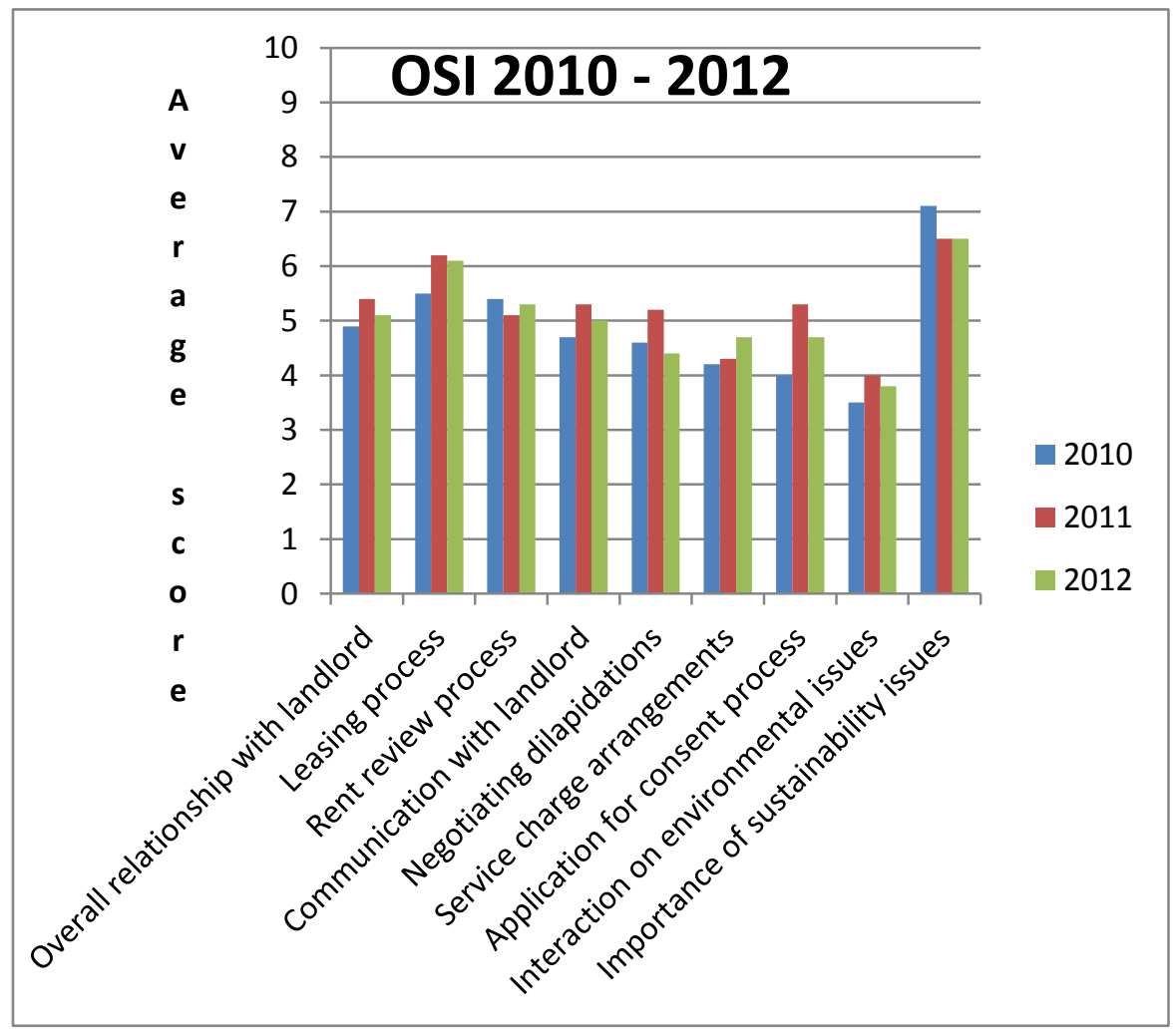

The studies described in this literature review were generally small, involving at most a few hundred respondents. The research which follows is based on a much larger sample of UK corporate occupiers, whose ratings of satisfaction with aspects of their tenancy enable an assessment of determinants of occupiers' overall satisfaction, loyalty and advocacy to be made. 


\section{Data and Method}

This research uses an original data set created from transcripts of 1334 interviews with occupiers of rented office buildings. The interviews were conducted between 2003 and 2013 by RealService, an independent consultancy for the UK property industry, specialising in helping landlords and property managers to meet the needs of occupiers by conducting occupier satisfaction studies on behalf of landlords, and writing reports to help property managers improve the service they deliver. 100 of the interviews were with the property directors of many of the largest UK businesses, who were asked for their opinions about the characteristics of the ideal landlord. The remaining interviews were with owners, CRE managers, office managers and facilities managers of businesses renting offices in the UK.

When landlords commission surveys, discussions are held with each to decide what aspects should be included in the questionnaire used by interviewers. Interviews are conducted face-to-face or by telephone, and typically include around 20-30 questions, and although similar topics are generally covered, the same questions are not necessarily asked in different projects. This means that in the interviews used for this research more than 400 different questions were asked, covering approximately 50 general topics.

Interviews were scheduled in advance, at a time to suit the interviewee. All interviews began with an explanation of the purpose of the interview and confirmation that the interviewee was qualified to give an opinion on their organisation's satisfaction with aspects of the property and property management. Respondents were told that they could make "off-the-record" comments if they wished, or could remain anonymous, but were encouraged to be open and honest with their feedback so that their landlord or managing agent could act on the feedback to improve the service they deliver.

The interviews generally asked occupiers for their opinions about each aspect of their occupancy, and the responses were hand-written during the interview and subsequently transcribed and entered into an SQL database. Although interviews were sometimes recorded, with the interviewees' permission, this was for quality control and training rather than to assist with the subsequent transcription. After an interview had been entered into the database, a ratings check was performed by another person, to ensure the values entered were those initially written during the interview.

The questionnaires themselves are confidential and the intellectual property of RealService Ltd. For all questions, occupiers were asked to give qualitative answers, discussing their feelings about the service, instances of good or bad service and key issues of importance to respondents and their colleagues. Where applicable, these responses were supplemented by a quantitative rating. The system of ratings was explained: respondents were asked to rate their satisfaction, or the quality of service, “on a scale of ' 1 ' to '5' where '1' represents 'very dissatisfied' or 'very poor' and '5' represents 'very satisfied' or 'excellent'. The rating was done after the qualitative discussion, so that it is a considered score that summarises their opinion in a quantitative way. 
Table 2 gives examples of questions that were asked of interviewees during occupier satisfaction studies:

Table 2: Typical Questions in an Occupier Satisfaction Study of a Property

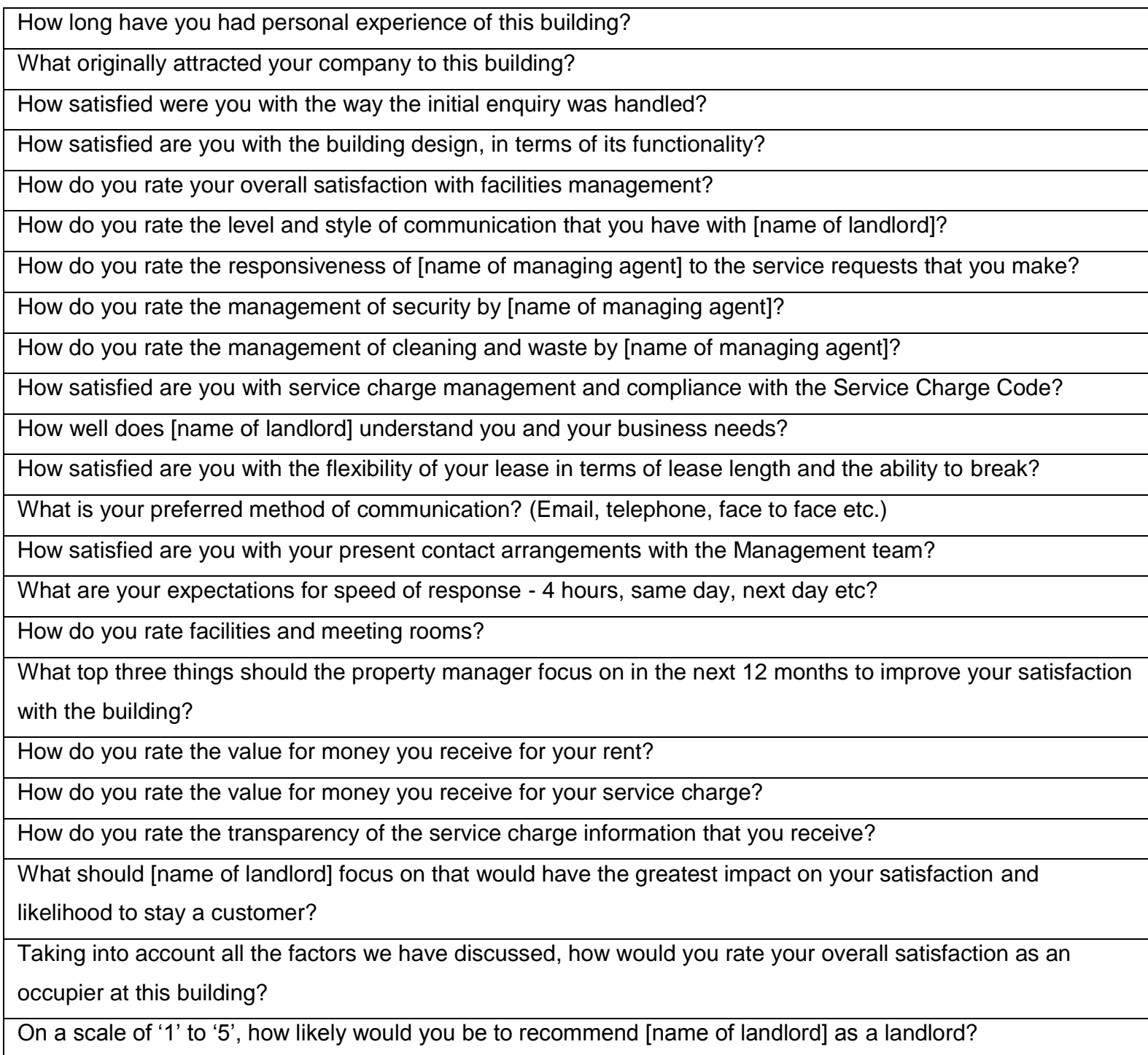

\section{Explanation of Variables}

The ratings given by occupiers in response to the interview questions are used as variables in the analysis. Most interviews included questions about satisfaction with communication with the property manager, their responsiveness to requests, and the extent to which the property manager understood the business needs of the occupier. 'Building Specification' incorporates satisfaction with the form and function of the office building, its image, layout, and build quality, depending upon which variant of question was asked of occupiers.

'Cleaning' refers to the cleaning of common parts, usually paid for as part of the Service Charge, but can also include cleaning within the demise if this is organised by the landlord or their agent. 
Similarly, 'Maintenance' refers to any maintenance of the building that is the landlord's responsibility. 'Waste and Recycling' is grouped into a single question, although there is some overlap with 'Corporate Social Responsibility', because some occupier satisfaction studies included several questions about sustainability and environmental initiatives, of which 'Recycling' is one. Questions about occupiers' satisfaction with 'Waste and Recycling' were not asked if they were not the landlord's responsibility, unless the landlord or managing agent had encouraged occupiers to collaborate to have a single waste collection service to achieve economies of scale.

Questions about 'Entrances / Reception' encompass the lobby of an office building. Surveys usually included questions about satisfaction with HVAC (Heating, Ventilation and Air-Conditioning) and Lighting, and the reliability of lifts in a building. Many studies asked about satisfaction with Amenities or Services; these could be within the property, or perhaps in the vicinity. Only about onequarter of interviews asked about satisfaction with the Leasing Process, in part because the interviewee may not have been involved in the actual leasing.

The 'Professionalism' category refers to the professionalism of the property manager, and includes questions about occupiers' perception of being treated as a valued customer and of the customer service they receive. 'Billing and Documentation' relates to the accuracy, transparency and timeliness of documentation such as service charge budgets and reconciliations. 'Approvals and Legal Processes' includes applications for licenses, such as those required under the terms of the lease if the occupier wishes to make alterations to the property. It also incorporates requests to assign or sub-let the property.

All occupier satisfaction studies included a summary question, at the end of interviews, which asked occupiers to give a summary rating of their overall satisfaction, taking into account all the aspects that had been discussed during the interview. As well as this question on 'Overall Satisfaction', many interviews also asked occupiers earlier on in the interview to summarise their overall satisfaction with property management, and some asked occupiers to rate their landlord's performance on the scale of ' 1 ' to ' 5 ' that was used for almost all questions. Approximately one-quarter of interviews, mainly those conducted in the earlier years, asked occupiers to rate their lease renewal intentions: how likely they were to renew their lease if the decision had to be taken today. Other questions used as dependent variables in the analysis include occupiers' ratings of their perception of receiving value for money for rent and their willingness to recommend their landlord.

Table 3 shows the pairwise correlations of the ratings given by occupiers to the survey questions with their rating of overall satisfaction. From this it can be seen that all correlations are positive, and most are statistically highly significant. Satisfaction with property management shows the strongest correlation with overall satisfaction, with other relationship aspects such as understanding needs, responsiveness and communication also showing strong positive correlations. The question about satisfaction with the Tenant Mix in an office building was asked in only 15 interviews, so its statistical significance is lower. 
Table 3: Pearson Correlations with Overall Satisfaction for Office Occupiers ${ }^{2}$

\begin{tabular}{|c|c|c|}
\hline & $\begin{array}{l}\text { Pearson Correlation } \\
\text { with Overall Satisfaction }\end{array}$ & $\mathbf{N}$ \\
\hline Overall Satisfaction & 1 & 997 \\
\hline Property Management & $.646^{\star \star}$ & 508 \\
\hline Tenant mix & $.570^{\star}$ & 15 \\
\hline Understanding Needs & $.562^{\star \star}$ & 795 \\
\hline Corporate Social Responsibility & $.555^{\star \star}$ & 514 \\
\hline Responsiveness & $.552^{\star \star}$ & 947 \\
\hline Communication & $.548^{\star \star}$ & 957 \\
\hline Customer Service / Professionalism & $.524^{\star \star}$ & 699 \\
\hline Service Charge Value for Money & $.492^{\star \star}$ & 570 \\
\hline Building Specification & $.483^{\star \star}$ & 433 \\
\hline Entrances Reception & $.477^{\star \star}$ & 403 \\
\hline Maintenance & $.447^{\star \star}$ & 817 \\
\hline Rent Value for Money & $.447^{\star \star}$ & 546 \\
\hline Estate Satisfaction & $.427^{\star \star}$ & 36 \\
\hline Leasing process & $.418^{\star \star}$ & 338 \\
\hline Amenities \& Services & $.394^{\star \star}$ & 424 \\
\hline Cleaning & $.389^{\star *}$ & 871 \\
\hline Security & $.385^{\star *}$ & 804 \\
\hline Parking & $.371^{\star *}$ & 257 \\
\hline HVAC \& Lighting & $.360^{\star *}$ & 613 \\
\hline Trading performance & $.343^{\star *}$ & 124 \\
\hline Approvals \& Legal Processes & $.334^{\star *}$ & 260 \\
\hline Signage & $.323^{\star *}$ & 315 \\
\hline Lifts & $.323^{\star \star}$ & 348 \\
\hline Billing \& Documentation & $.318^{\star *}$ & 535 \\
\hline Location & $.289^{\star *}$ & 376 \\
\hline Public transport & $.271^{*}$ & 58 \\
\hline Marketing \& Events & $.228^{*}$ & 122 \\
\hline Waste \& Recycling & $.226^{\star *}$ & 134 \\
\hline Health \& Safety & $.189^{\star \star}$ & 204 \\
\hline \multicolumn{3}{|l|}{${ }^{\star \star}$. Correlation is significant at the 0.01 level } \\
\hline${ }^{*}$. Correlation is significant at the 0.05 level & & \\
\hline
\end{tabular}

\section{Analysis}

The first research question, corporate occupiers' opinions about the qualities of the ideal landlord, was addressed by categorising responses from interviews with 100 property directors of major companies in the UK, and presenting the responses in a bar chart. This highlights the characteristics of landlords that occupiers believe lead to an amicable, symbiotic relationship.

For the other research questions, the analysis used structural equation modelling (SEM) to show the factors that have most impact on occupier satisfaction and loyalty, and logistic regression to analyse determinants of occupiers' willingness to recommend their landlord.

\footnotetext{
${ }^{2}$ Correlations using the non-parametric coefficients Kendall's Tau and Spearman's Rho were also conducted, in case the ratings were not interval data in which gaps between consecutive scores are equal, but all coefficients produced very similar results. This is discussed further in the following Section.
} 
The determinants of occupier satisfaction and loyalty were established using structural equation modelling with SMART PLS. This software package has been used in marketing research to identify factors affecting consumers' behaviour, and is suitable for researching determinants of occupier satisfaction. In particular, it makes no assumptions about the distribution of data, so is not limited by the fact that the occupier satisfaction data in this study does not follow a normal distribution, but exhibits negative skewness and positive kurtosis. It is also able to analyse data which has missing fields, as is the case with the occupier satisfaction data used for this research, because different questions were asked of occupiers in different properties, as explained earlier.

Using SMART PLS, the researcher creates a model that shows postulated relationships between variables and constructs, and tests the strength and significance of the paths. The paths (relationships) are guided by prior research and theory. For this research, the structural models make use of the SERVQUAL dimensions, supplemented by two additional dimensions:

- $\quad$ 'Value for Money', since perception of receiving value for money has been shown in previous research to influence satisfaction (as discussed in the review earlier); and

- 'Property Management', to assess whether the SERVQUAL dimensions account fully for all aspects of property management, or whether additional factors are involved.

Variants of the model which exclude the last two dimensions are also examined and compared. Each construct comprises one or more formative indicators - variables that are deemed to "cause" the construct. The relationship between a construct and its indicators was tested using principal components analysis, and tests of cross-loadings of variables. These tests confirmed that each indicator loads most strongly onto the construct with which it is conceptually linked.

The dependent variables of interest are those that relate to satisfaction, loyalty and advocacy. The associated constructs are 'Total Satisfaction' and 'Reputation', each of which is measured by two reflective indicators (variables that are considered manifestations of the construct). 'Total Satisfaction' is measured by occupiers' assessment of their overall satisfaction and also their stated likelihood of lease renewal. 'Reputation' is assessed by occupiers' rating of their landlord's performance and their willingness to recommend their landlord or property manager.

As discussed earlier, all ratings are on a scale of ' 1 ' to '5'. Criticisms of attempts to perform quantitative analysis using ordinal response ratings have been made because of the difficulty in determining whether it is truly interval data i.e. whether the gaps between consecutive scores are equal. If a question asks "How would you rate your satisfaction ....?" with options "Very dissatisfied, dissatisfied, neutral, satisfied, very satisfied" then it is not clear that "satisfied" is twice as good as “dissatisfied”! However if the wording asks for a rating on a scale of ' 1 ' to ' 5 ' researchers have demonstrated the legitimacy of performing quantitative and statistical analysis (see for example Carifio \& Perla, 2007). Indeed Hair et al., (2014, p. 9) emphasise that a well-presented Likert scale, with symmetry about a middle item, is "likely to approximate an interval-level measurement" and that "the corresponding variables can be used in SEM". 
Tests of validity were conducted on the formative indicators, the reflective indicators and the structural (inner) model according to the protocols suggested by Hair et al. (2014). The indicators were assessed for multicollinearity and were found to have a maximum variance inflation factor (VIF) of 1.62, confirming that they are not excessively highly correlated. The results of tests for discriminant validity and composite reliability using AVE, the Fornell-Larcker criterion and HTMT ratios are not included in this paper but are available from the author upon request. The statistical significance of path weights was assessed by bootstrapping procedure; the large sample size means that almost all paths are statistically significant at $95 \%$, with most being significant at $99 \%(\mathrm{p}<0.01)$.

Coefficients of determination, $\mathrm{R}^{2}$, are calculated for each latent construct, i.e. the amount of variance explained in a latent endogenous construct; what constitutes a meaningful value varies according to the nature of the research. Hair et al. suggest that values of $0.75,0.5$ and 0.25 can be described as strong, moderate or weak (Hair, Ringle, \& Sarstedt, 2011). Hair et al. (2014) suggest using Cohen's (1988) guidelines for interpreting effect size, $\mathrm{f}^{2}$, namely that values of $0.02,0.15$ and 0.35 represent small, medium and large effects.

In addition to assessing the path weights and effect sizes, SMART-PLS was also used in this research to perform "Importance-Performance" analysis, creating a Matrix which helps service providers understand where to focus efforts to improve service delivery to achieve greatest impact (Haïr et al., 2014; Keiningham et al., 1999; Martilla \& James, 1977).

Robustness checks were conducted to assess the validity of results. These included using variants of the model and treating missing variables in three ways: pairwise deletion, mean replacement and "multiple imputation". Results are shown for the model variants using the pairwise deletion method, since this retains more of the variability in the data. The findings proved to be consistent whichever approach was used, and results for all methods are given in Sanderson (2015).

\section{Results}

\section{Research Question 1: What do corporate occupiers consider to be the characteristics of the ideal landlord?}

Figure 2 classifies the responses when 100 property directors of many of the largest corporate businesses in the UK were asked to give up to three characteristics that they consider to be most desirable in a landlord. 
Figure 2: Property Directors' Opinions about the Characteristics of an ideal Landlord

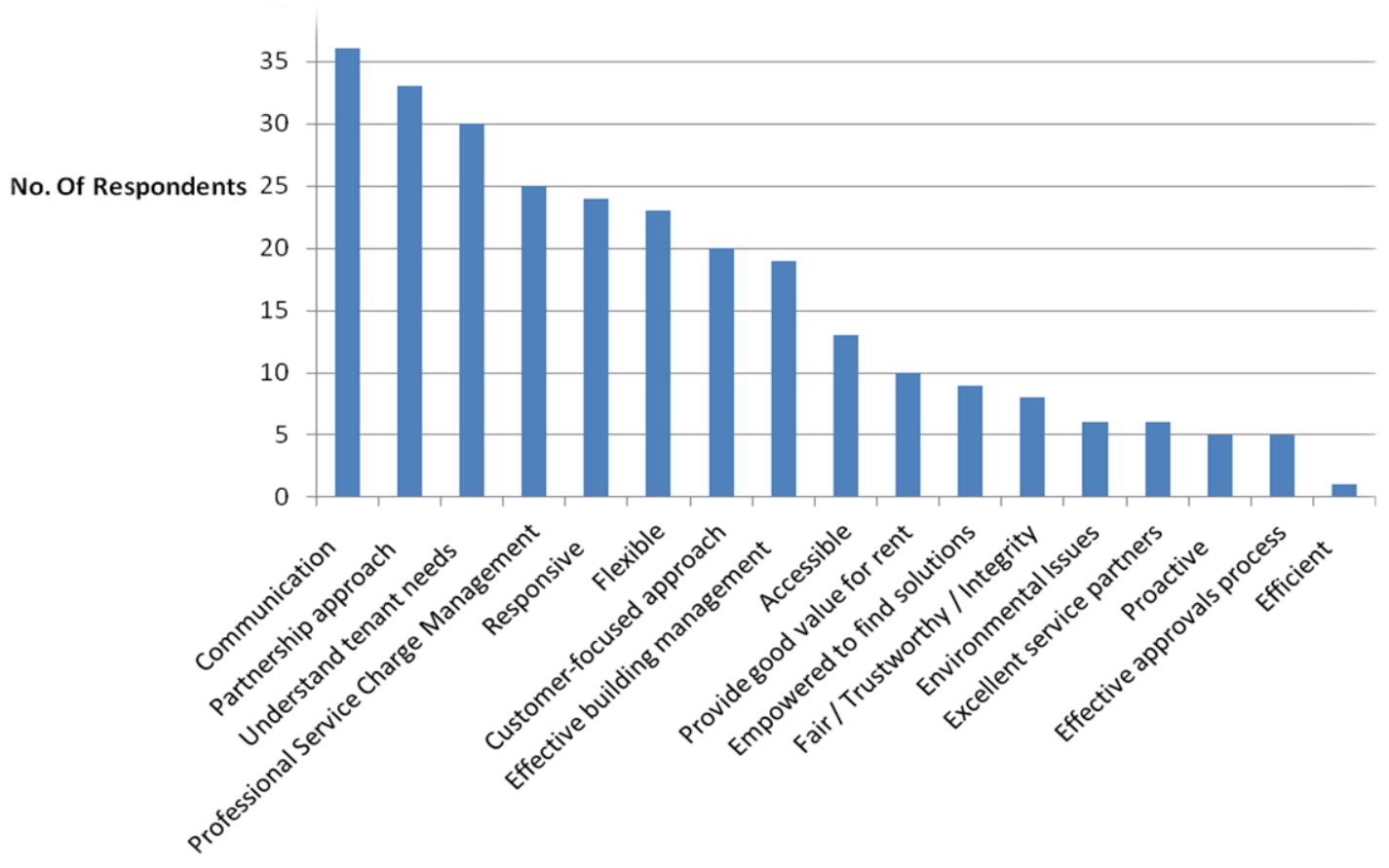

The general consensus amongst corporate property directors was that a good landlord should understand the needs of the occupier, be flexible and communicate with the tenant, adopting a partnership approach. Respondents require:

"Flexibility, and a willingness on the part of the landlord to strike deals in response to changing market conditions".

Property directors also emphasized the importance of good service charge management, with timely budgets, transparency about costs and clear documentation.

Interviewees were also asked what landlords need to do to improve the landlord - tenant relationship. The most frequently cited suggestion was "Communication", which, as shown in Figure 2, was also considered the most important quality in a landlord. Related suggestions included the need to "build relationships with tenants", "to have a single point of contact so that occupiers know who to speak to", "closer liaison with tenants", and "a better understanding of tenants' business needs." Other suggestions related to value for money for service charges, and to flexibility - "lease flexibility", "flexibility of approach" and "flexibility with licenses for alterations".

The remaining analysis relates to the quantitative responses from the interviews with owners, CRE managers, office managers and facilities managers of businesses renting offices in the UK, for which correlations with Overall Satisfaction were presented in Table 3. 


\section{Question 2: What are the determinants of occupier satisfaction?}

Figure 3 shows the path diagram with path weights for formative indicators, path loadings for reflective indicators and $\mathrm{R}^{2}$ for latent constructs. From this, the relative importance of the formative indicators on the latent constructs can be seen. Thus, for example, Corporate Social Responsibility, the Leasing Process and Professionalism are of most importance in explaining 'Assurance', whilst Security appears less influential. For the 'Empathy' construct, the two formative indicators are of similar importance, whilst for the 'Reliability' construct, Documentation and Maintenance have the greatest impact (the highest path weights). Responsiveness to requests is of greater importance than Legal processes for the 'Responsiveness' construct, whilst Amenities, the form and function of the office building and its location are of most importance in the 'Tangibles' construct. Value for Money for Rent is of more importance than Value for Money for Service Charge.

In the model, occupiers' overall satisfaction (the latent construct 'Total Satisfaction') is measured by two reflective indicators, of which the overall satisfaction variable has a higher loading than the variable 'lease renewal intention'. For the Landlord 'Reputation' construct, occupiers' willingness to recommend their landlord has a higher loading than the variable created from occupiers' rating of landlord performance. The coefficients of determination are shown inside the constructs in the structural model. The values for 'Property Management', 'Total Satisfaction' and 'Reputation' are all 'Moderate', according to the suggested criteria of Hair et al. (2014) referred to earlier, whilst $\mathrm{R}^{2}$ for 'Value' is 'Weak'.

\section{Figure 3: Path Diagram for Office Occupiers}

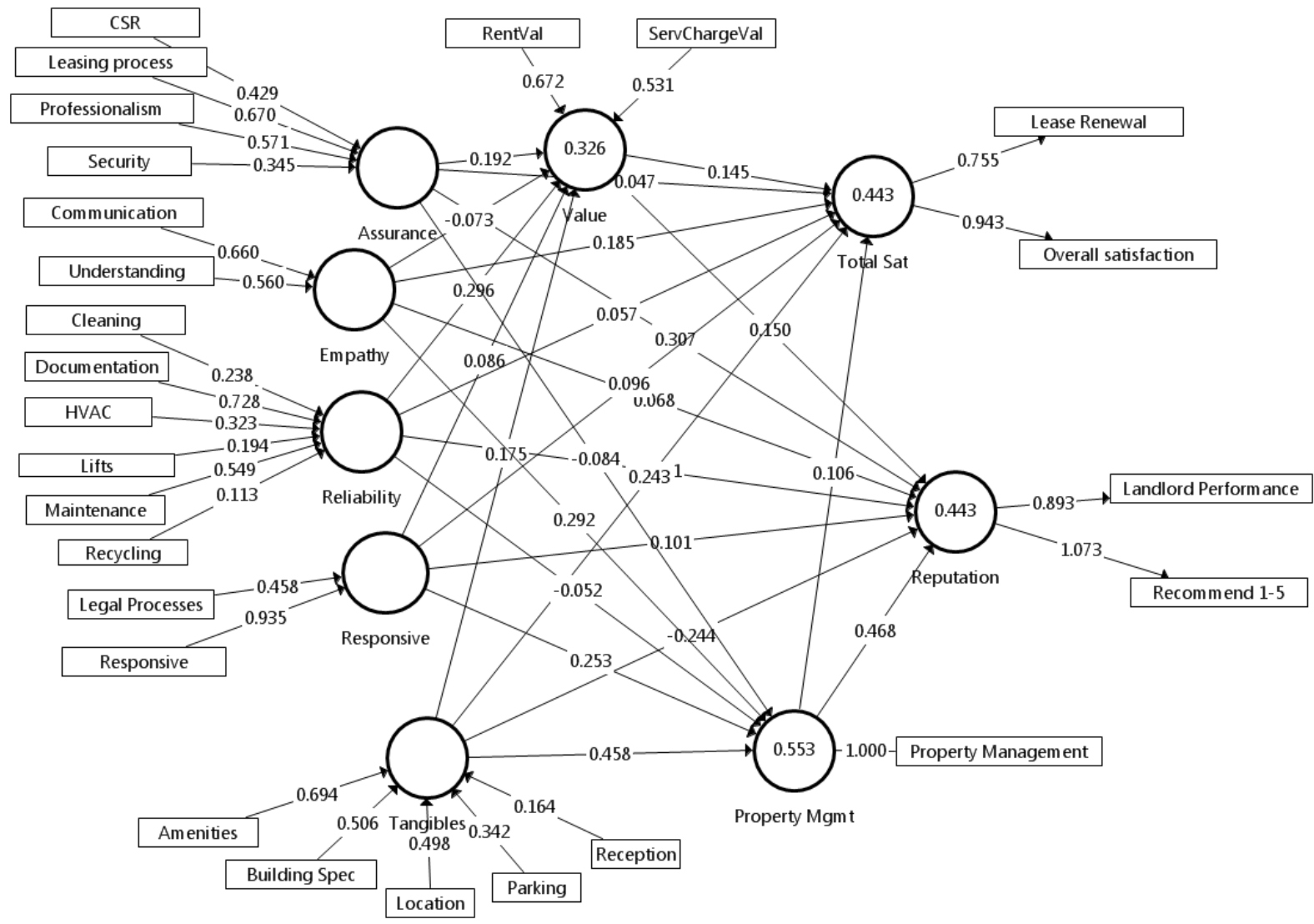


Table 4 gives the total effects, combining both direct and indirect paths, of the latent constructs on the four dimensions of interest in this research, for several model variants to check the reliability of the results. It can be seen that the paths with the greatest effect are the following:

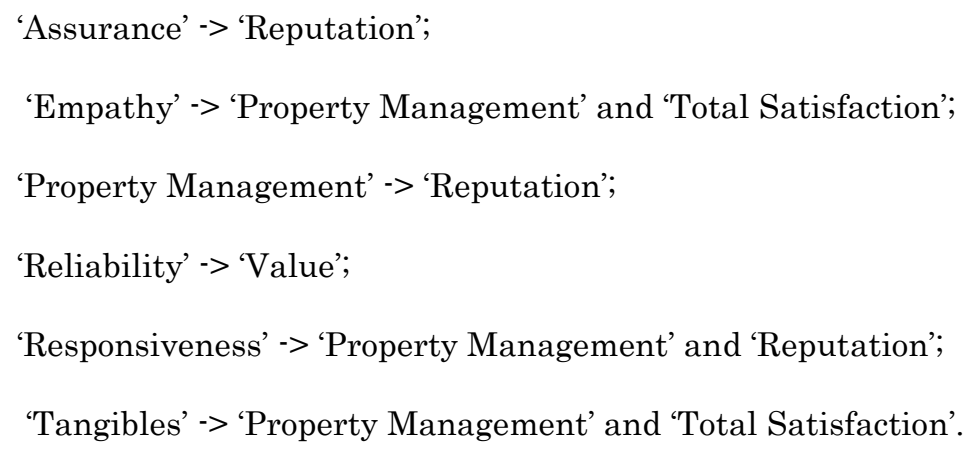

The size of the effects are given in Table 5, from which it can be seen that most effects are 'small', using Cohen's (1988) criteria, but the effect of 'Property Management' on 'Reputation' is 'moderate' and that of 'Tangibles' on 'satisfaction with 'Property Management' is 'Large'.

Table 4: Paths in the Structural Model for Office Occupiers' Satisfaction (including robustness tests using model variants)

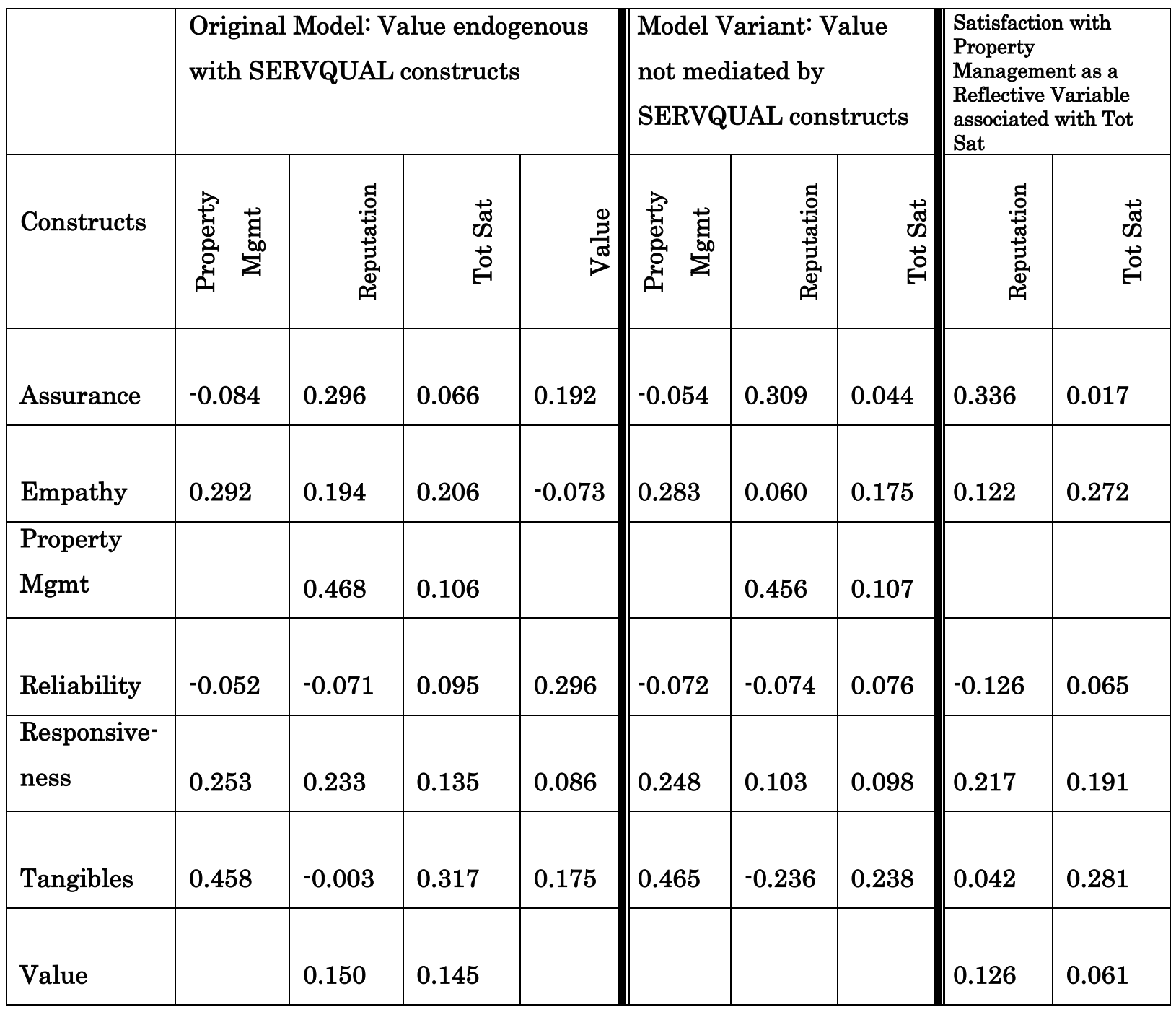


Table 5: Effect Size of Constructs

\begin{tabular}{|c|c|c|c|c|}
\hline F-Sq Offices & Property Mgmt & TotSat & Reputation & Value \\
\hline Assurance & 0.010 & 0.003 & $0.090+$ & $0.027+$ \\
\hline Empathy & $0.103+$ & $0.029+$ & 0.002 & 0.005 \\
\hline Property Mgmt & & 0.007 & $0.218++$ & \\
\hline Reliability & 0.010 & 0.003 & 0.005 & $0.075+$ \\
\hline Responsiveness & $0.069+$ & 0.007 & 0.006 & 0.005 \\
\hline Tangibles & $0.404+++$ & $0.043+$ & $0.087+$ & $0.031+$ \\
\hline Value & & $0.023+$ & $0.034+$ & \\
\hline
\end{tabular}

The Importance - Performance Matrix for Occupiers' Overall Satisfaction is drawn by plotting occupiers' ratings of satisfaction with aspects of their tenancy against the importance of these aspects on their overall satisfaction, as determined by the structural equation modelling. The ratings of satisfaction serve as a proxy for the performance of the landlord or property manager in supplying each aspect of service. The values are re-scaled to range from $0-100$ rather than the $1-5$ ratings given by occupiers. The importance is inferred from the path coefficients from the structural equation modelling.

Table 6 shows the data that is used to generate the graph, with variables ordered from lowest to highest performance and from highest to lowest importance. The office occupiers in these studies perceive low performance for Heating, Ventilation and Air Conditioning and for Legal Processes such as the response to requests for licenses to make alterations and the rent review process. The Building and its Location, Communication, and Understanding Business Needs, all achieve relatively high performance ratings. The Indicators which most affect Total Satisfaction amongst Office Occupiers are the Office Building itself, its Location and Amenities, and aspects which relate to the relationship with the landlord or property manager: Communication, Responsiveness, Understanding of Business Needs, and Property Management overall.

The positive trend of the data points on the Importance - Performance Matrix (Figure 4) implies that, in general, satisfaction is higher for those aspects that are of greater importance, a finding that should give some reassurance to owners, managers and occupiers alike. The indicators that lie below and to the right of a line of best fit are Amenities and Value for Money for Rent. These are closest to the bottom-right quadrant of the Importance - Performance Matrix i.e. of high importance but low performance. Therefore property managers should liaise closely with occupiers to determine which 
additional amenities would be appreciated, and discuss the financial implications of supplying such amenities.

Table 6: Performance of Indicators and their Importance for Occupiers' overall satisfaction

\begin{tabular}{|c|c|c|c|}
\hline Indicator & $\begin{array}{c}\text { Indicator } \\
\text { Performance }\end{array}$ & Indicator & $\begin{array}{l}\text { Importance for } \\
\text { Total Satisfaction }\end{array}$ \\
\hline HVAC & 47.020 & Building Specification & 0.120 \\
\hline Legal Processes & 48.993 & Location & 0.101 \\
\hline Rent Value & 51.040 & Amenities & 0.099 \\
\hline Documentation & 54.376 & Communication & 0.083 \\
\hline Recycling & 55.117 & Responsiveness & 0.072 \\
\hline Service Charge Value & 55.808 & Understanding Needs & 0.061 \\
\hline Lifts & 56.892 & Property Management & 0.060 \\
\hline CSR & 57.331 & Rent Value & 0.046 \\
\hline Amenities & 57.842 & Parking & 0.040 \\
\hline Lease Renewal & 59.145 & Service Charge Value & 0.038 \\
\hline Leasing process & 61.232 & Documentation & 0.031 \\
\hline Parking & 62.125 & Maintenance & 0.030 \\
\hline Professionalism & 63.662 & Reception & 0.030 \\
\hline Security & 65.270 & Legal Processes & 0.023 \\
\hline Maintenance & 65.952 & Professionalism & 0.020 \\
\hline Property Management & 66.120 & HVAC & 0.017 \\
\hline Responsiveness & 66.660 & Leasing process & 0.016 \\
\hline Landlord Performance & 66.832 & CSR & 0.016 \\
\hline Reception & 67.166 & Security & 0.014 \\
\hline Cleaning & 67.229 & Cleaning & 0.014 \\
\hline Communication & 68.011 & Lifts & 0.010 \\
\hline Understanding Needs & 69.438 & Recycling & 0.004 \\
\hline Overall Satisfaction & 71.733 & & \\
\hline Location & 76.437 & & \\
\hline Building Specification & 78.008 & & \\
\hline Recommend 1-5 & 78.147 & & \\
\hline
\end{tabular}




\section{Figure 4: Importance - Performance Matrix: Office Occupiers' Overall Satisfaction ( $x$-axis shows}

importance, y-axis shows performance)

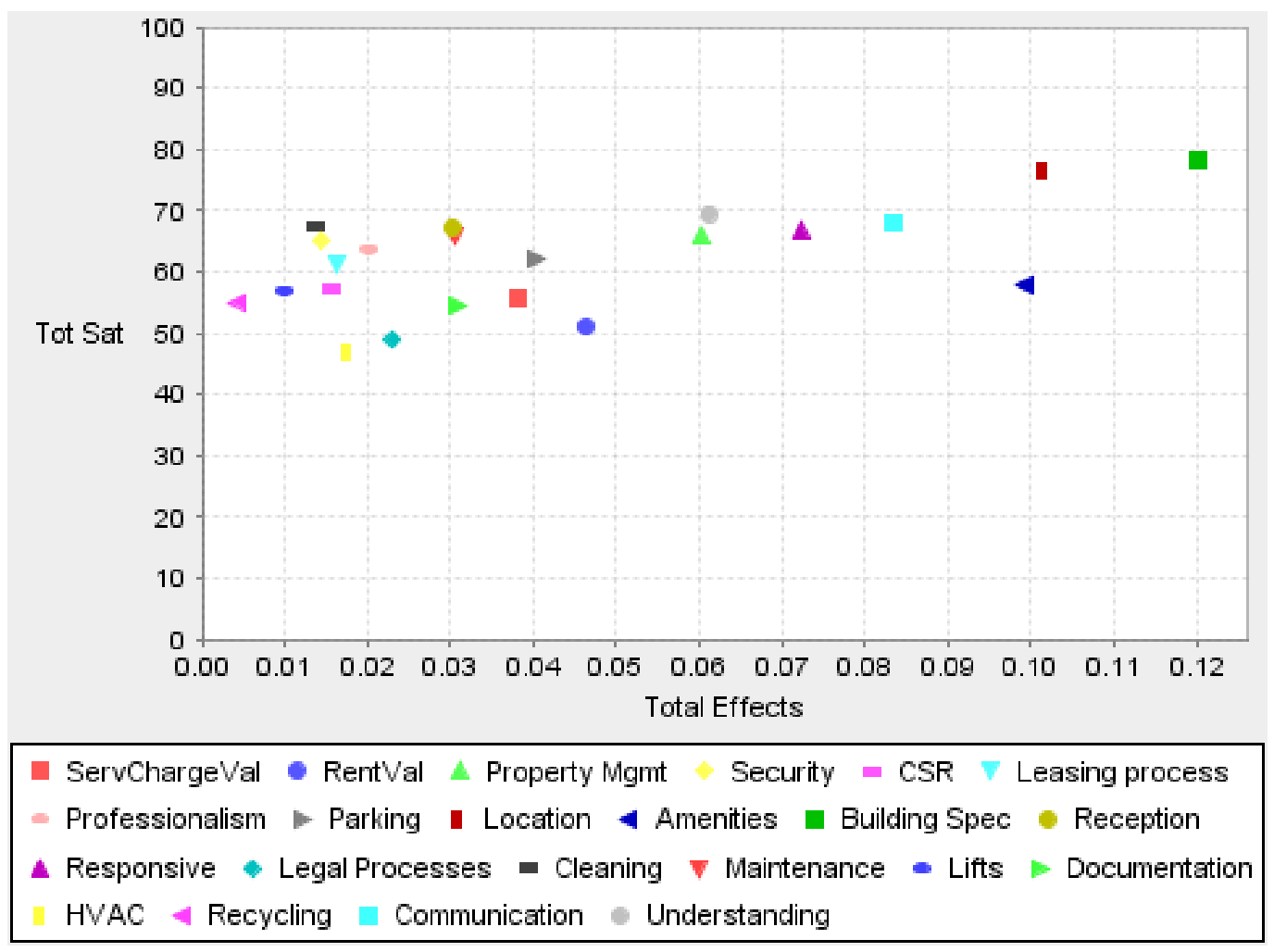

Similar analysis was carried out for the other latent variables: the 'Property Management' construct, 'Reputation' and 'Value'. The key findings for these were:

- Office occupiers' satisfaction with property management depends mainly upon 'Tangible' aspects of their tenancy: the office building, its location and the amenities provided and also upon their property manager's responsiveness to requests, and by their communication and understanding of occupiers' business needs. These factors are very similar to those affecting occupiers' overall satisfaction.

- Satisfaction with 'Property Management' has the largest impact on office occupiers' perception of the reputation of their landlord; 'Assurance' (primarily Professionalism and Corporate Social Responsibility) and 'Responsiveness' are also important.

- For maximum impact on perception of reputation amongst respondents in this sample, landlords and property managers should focus on making legal processes more straightforward, giving demonstrable value for money for rent, and responsiveness to occupiers' requests.

- The factor of most importance in determining office occupiers' satisfaction with Value for Money is the 'Reliability' of the service they receive; for office occupiers, the main determinants of 'Reliability' are the accuracy and clarity of documentation and the maintenance of their building. 


\section{Question 3: What are the determinants of occupier loyalty (measured by their stated likelihood of lease renewal)?}

Figure 5 gives the results of the model in which lease renewal intentions are considered dependent upon the SERVQUAL dimensions, 'Property Management' and 'Value'. The coefficient of determination, $\mathrm{R}^{2}$, is 0.52 , implying the model explains $52 \%$ of the variance in lease renewal intentions for these office occupiers. The path diagram shows that most of the constructs influence office occupiers' loyalty, apart from 'Property Management' as a separate construct.

Figure 5: Path Diagram for Lease Renewal Intentions of Office Occupiers

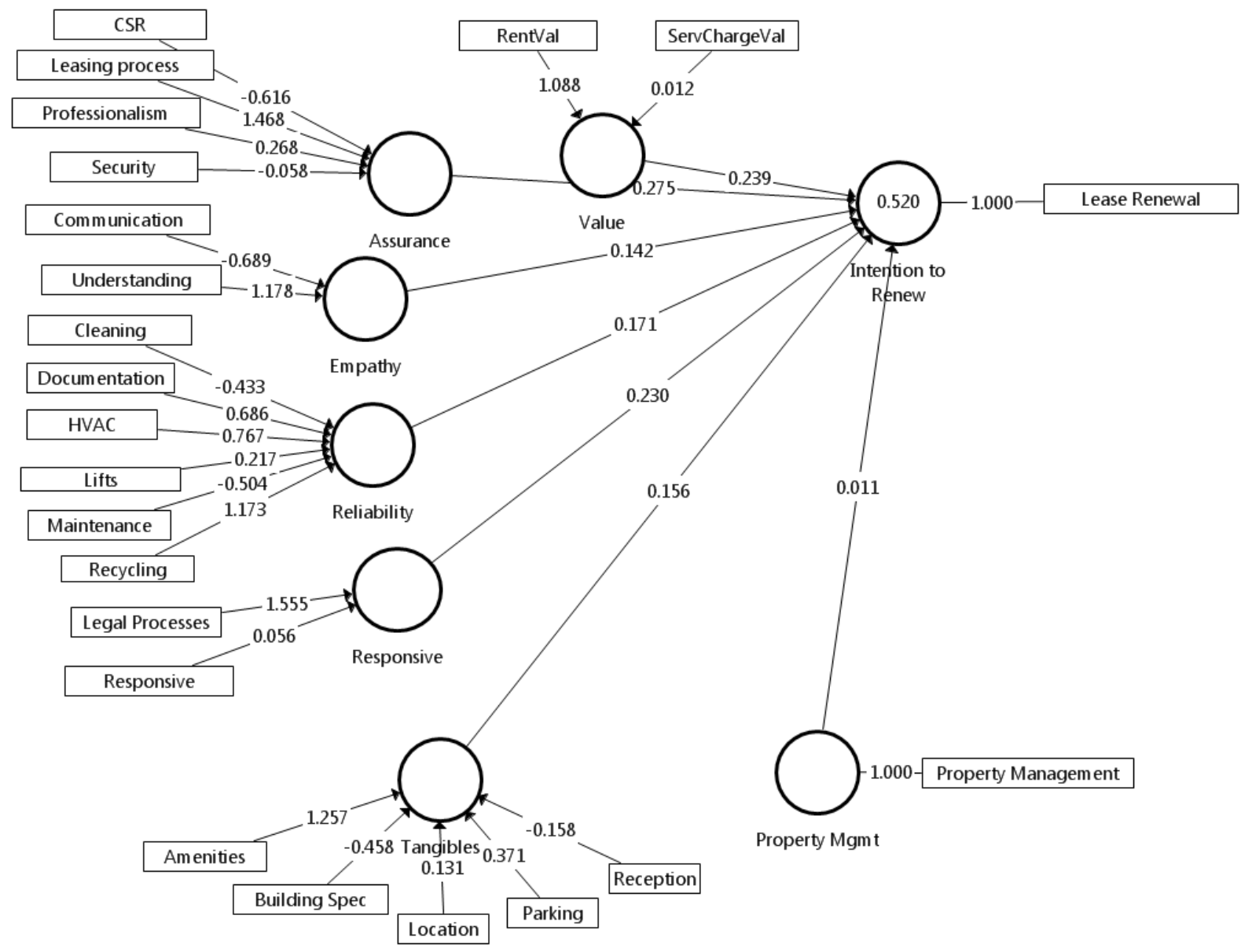

From Figure 6, it can be seen that 'Assurance' has the largest effect size, with 'Responsiveness' and 'Value' also playing a role in the decision-making process. The paths which are statistically significant following Bootstrapping are 'Assurance' ( $p=0.001)$, 'Empathy' ( $p=0.043)$, 'Responsiveness' $(p=0.008)$, and 'Value' ( $p=0.001)$. The key formative indicators in the decision to renew would appear to be value for money for rent, the leasing process, legal processes, and office amenities. Whilst satisfaction with the building itself is generally high, it appears to be of low importance in lease-renewal decisions. This finding supports previous research which shows that lease renewal rates are lower for offices than for other sectors of UK Commercial property (Frodsham, 2010; IPD et al., 2013; IPD \& Strutt \& Parker, 2012) - if there is less attachment to the actual building, there may be fewer barriers to "defecting". 
Figure 6: Effect Size for Office Occupier Loyalty

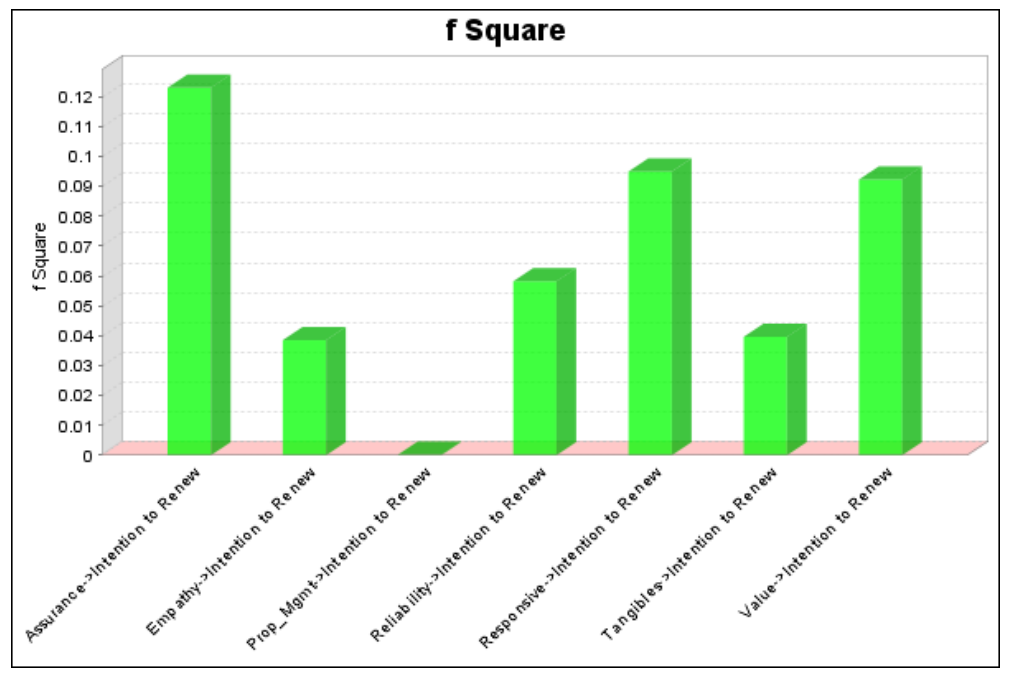

From the Importance - Performance Matrix (Figure 7) it can be seen that there is a negative relationship between the performance of the indicators for likelihood of lease renewal and their importance. Aspects where performance is perceived to be high are actually those of less importance in determining lease renewal. The key formative indicators listed above are those which offer the greatest scope for increasing occupiers' stated likelihood of lease renewal for both methods of treatment of missing data: value for money for rent, the leasing process, legal processes and office amenities.

Additional analysis using multinomial logistic regression found Value for Money for Rent to be the main determinant of lease renewal intentions, highlighting the need for landlords to provide value for money and to be transparent about costs so that value can be understood and appreciated.

Figure 7: Importance - Performance Matrix for Likelihood of Lease Renewal

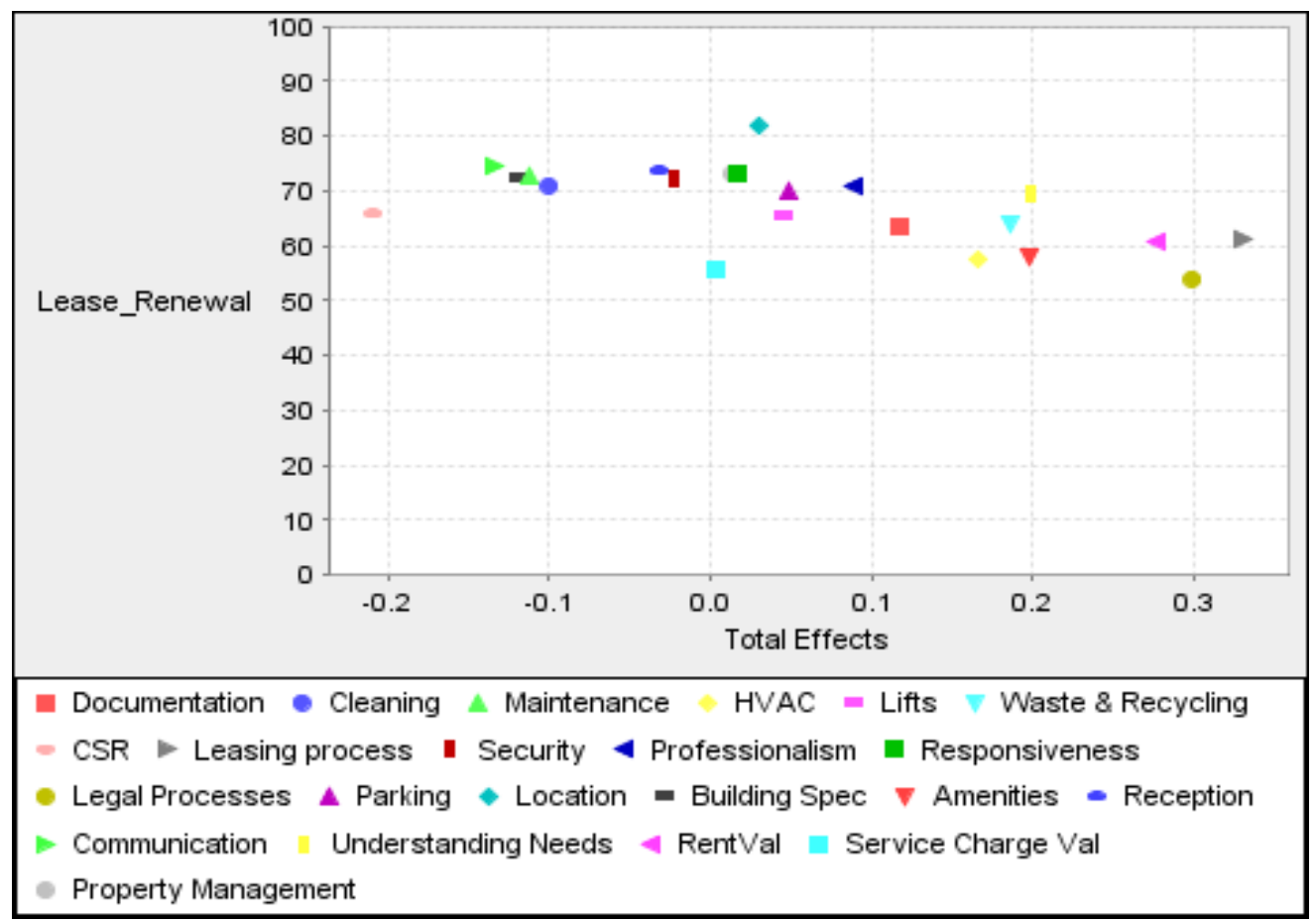




\section{Question 4: What are the determinants of occupiers' willingness to recommend their landlord or property manager?}

To answer this research question, the variable in which occupiers' rating of their willingness to recommend their landlord was converted into a binary variable in which a rating of ' 5 ' was treated as 'Yes' while a rating of ' 1 ' to '4' was treated as 'No', analogous to the 'Net Promoter' concept (Reichheld \& Teal, 1996; Reichheld, 2003) in which customers are asked to rate their willingness to recommend a service provider, using a scale of ' 1 ' to ' 10 ', with those rating ' 9 ' or ' 10 ' being deemed 'Promoters'.

Binary logistic regression was conducted using the SERVQUAL dimensions as explanatory variables. The resulting odds ratios are shown in Table 7, in the column Exp (B).

For office occupiers, the best predictors of 'Willingness to Recommend' are 'Assurance' and 'Empathy', For each unit increase in satisfaction with 'Assurance', the odds of an occupier rating as ' 5 ' their willingness to recommend the landlord increase by a factor of about 4.8. For 'Empathy', the figure is about 1.8. The correlations with 'Willingness to Recommend' of the individual variables which comprise the SERVQUAL dimensions are all highly significant. Advocacy is mainly influenced by the professionalism of the property manager, occupiers' satisfaction with the leasing process, the perception that the landlord is a responsible corporate citizen, and that the property manager understands the occupiers' business needs and communicates effectively.

Table 7: Determinants of office occupiers' willingness to recommend their landlord: Odds Ratios

\begin{tabular}{|c|c|c|}
\hline $\begin{array}{l}\text { SERVQUAL Dimensions for Predicting } \\
\text { Advocacy ('5' on scale of ' } 1 \text { ' - '5') }\end{array}$ & $\operatorname{Exp}(B)$ & $\begin{array}{l}\text { Statistically significant item correlations with } \\
\text { 'willingness to recommend' }\end{array}$ \\
\hline \multirow[t]{4}{*}{ Assurance** } & 4.78 & Customer Service / Professionalism** \\
\hline & & Leasing Process** \\
\hline & & Corporate Social Responsibility** \\
\hline & & Security** \\
\hline \multirow[t]{2}{*}{ Empathy $* *$} & 1.77 & Understanding Needs** \\
\hline & & Communication** \\
\hline \multirow[t]{3}{*}{ Tangibles } & 1.20 & Entrances / Reception** \\
\hline & & HVAC / Lighting** \\
\hline & & Building Specification* \\
\hline \multirow[t]{3}{*}{ Reliability } & 1.18 & Maintenance** \\
\hline & & Billing \& Documentation** \\
\hline & & Cleaning* \\
\hline \multirow[t]{2}{*}{ Responsiveness } & 1.06 & Responsiveness** \\
\hline & & Approvals / Legal Processes** \\
\hline
\end{tabular}




\section{Discussion of Results and Implications for Property Managers and Corporate Occupiers}

This research has demonstrated that the most influential factors in achieving occupier satisfaction, loyalty and advocacy amongst UK office tenants are (i) the physical aspects of the property; (ii) the empathy of the property manager; (iii) the assurance that an owner or managing agent can give the customer; and (iv) perception of receiving value for money in terms of the overall office occupation. This section discusses the combined impact of these features, drawing out any insight that the research offers for owners, corporate occupiers and managing agents in turn, and making suggestions as to how this might affect their work. The paper ends by discussing the nature of owner-customer relationships and trust and making recommendations for how the property industry as a whole can move this subject forward.

\section{Owners' capital investment strategies}

The physical aspects of most importance to the corporate occupiers in this study are the specification, form and function of the property, its location, and the amenities within the building and in the vicinity. The property itself is crucial, offering scope for landlords to improve occupier satisfaction and reduce the risk of defection by keeping it up-to-date, echoing the findings of Appel-Meulenbroek, (2008). Property trading to improve the quality of an investor's overall portfolio is an obvious strategy. For owners and managers with more limited trading potential, cost benefit analysis of different refurbishment strategies will need to be undertaken to arrive at appropriate capital investment levels for ageing properties. Also, given the inflexibility of location, innovative approaches to amenity provision might be employed to enhance the value to customers of a poorly located building. For example, employee buses might compensate for a location some distance from public transport hubs. Similarly, an ageing building with limited ability to boost a customer's profile might be given a foyer makeover. In such cases, what is crucial is that investment decisions are made on an informed basis: eliciting priorities from the customers themselves through simple discussion will allow a manager to target resources most effectively, involving a two-step process of (i) analysis of customer dissatisfaction, (2) review and agreement of remedial investment.

The perception of receiving value for money is the key determinant of occupiers' loyalty i.e. their stated likelihood of renewing their lease. This was found to depend upon the reliability of the property management service and the transparency of service charge documentation. It is therefore crucial that owners are very careful to account capital improvements accurately and ensure that no such items reach the service charge. It also depends upon property managers using their knowledge and buying power to arrange for services to be supplied in a cost-effective way, and using their expertise to offer advice to occupiers to enable the latter to obtain good value from their tenancy. 


\section{Corporate managers' property selection strategies}

In terms of corporate occupiers, a long term perspective is demanded when choosing a property to rent: occupiers should consider carefully whether it is likely to meet their current and future needs, and whether the amenities and service provision are suitable (Sanderson \& Edwards, 2014). For the occupiers in this research, amenities are considered inadequate in many cases. Heating, ventilation and air-conditioning are also found to be important but sometimes unsatisfactory. Ironically, despite property being the second highest annual cost for corporate customers, few conduct adequate due diligence before investing in a new property. New corporate customers should routinely request customer satisfaction survey data from previous occupiers and full disclosure of the age, state of repair and sufficiency assessments of heating, ventilation and air-conditioning. Negotiation of service contracts should focus on performance and response rates, with service charge rebates for delayed restoration of disrupted utilities. Since the customer is effectively paying for the managing agent through the service charge, they should be entitled to some redress for inadequate or inefficient building management. Value for money is an important customer requirement in office occupation, and corporate occupiers should be acutely aware of their total overall costs of occupation (IPD Occupiers, 2013), and be able to make comparisons with the costs they would incur if they were to own, rather than rent, their property. Occupiers should be proactive about requesting changes to processes that they perceive to be inefficient, as well as querying expenditure they feel to be unnecessary.

\section{Prioritising Improvements by Managing Agents}

Use of Importance-Performance matrices should be routinely employed by property managers when prioritising all aspects of their work. The Importance-Performance matrices shown in this paper relate to the responses from the 1334 occupiers in this study. However, each building is different, and each owner-customer relationship is unique. Therefore property managers and occupiers should work together, at an individual property level, to establish which specific aspects of property management are of high importance to occupiers but perceived to be of low performance. With such information, property managers can ensure that the services that they prioritise have the greatest impact on occupier satisfaction, loyalty and advocacy

\section{Building relationships}

This research has shown that customers want property owners and their agents to have some empathy for their own business: in short, customers want to be understood. Improvements in this area need to come from two directions: global and local. At the global level, we believe that there is a clear role for the educators and trainers of property professionals to include study of different business sectors in their curriculum. Whereas the manager of a landed estate would not dare to interact with agricultural, forestry or utilities customers without the confidence gained from a basic understanding of their underlying practices and the workings of their industry and marketplaces, few general real estate managers could boast such skills. Higher education and training programmes need to expand horizons beyond the narrow confines of real estate studies and encompass wider business analysis skills. The real estate profession as a whole needs greater awareness of its own position and role within global 
business markets. At the local level, managing agents need to spend time building relationships based on mutual understanding and trust.

Research in Australia has shown that empowerment, restraint of power and responsiveness are the main determinants of trust in retail tenants in shopping centres (Roberts et al., 2010). Owners can build trust with occupiers by not excessively exercising power at rent reviews. Whilst this recommendation might seem insufficiently commercial, it is wise to remember a fact that many businesses in other sectors have long since traded on: small concessions to ensure the retention of a good customer can prove a sensible value judgment given the transaction costs of securing new customers. Proper empathy depends upon property management staff having the necessary listening skills, open attitudes and motivation to develop a close, professional working relationship with occupiers. The partnership approach desired by occupiers does, of course, place obligations on both partners, for example openness and transparency in order to understand the pressures and requirements of each others' business. It also demands time.

Like empathy, the extent to which a customer feels 'assurance', depends upon the professionalism of the owner and service provider, and encompasses trust and reassurance. Assurance is particularly influential in a customer's willingness to recommend their landlord or property manager, and in the overall reputation of the landlord. At the micro level, trust between individuals and/or organisations is based on the decision of one party to rely on another party under conditions of risk. At this level it is acknowledged that trust has three dimensions: trusting someone builds on a decision which is based on an assessment of the other party's competence, integrity and benevolence (Bachmann \& Inkpen, 2011). Individual property owners and managers can therefore gain assurance from their customers through their everyday interactions by (i) demonstrating professional competence in the legal, technical and financial management of property; (ii) ensuring ethical, transparent and accountable practices; and (iii) demonstrating a positive attitude and responsiveness to requests in the way in which the property is managed. In such cases, the property owner and customer might never meet, and the managing agent functions as a 'third-party guarantor' playing an essential role in trust development, bridging each party's knowledge domains and making judgments on behalf of the owner. In this respect, owners need to be absolutely confident that their interests are best represented through very careful and regular evaluation of managing agents. The criteria through which owners might conduct such evaluations can be informed by research into how to develop trust at the relationship growth stage, which has found that the crucial factors in the development of ability trust are performance, expertise and communication. With respect to the development of integrity trust, honesty, integral actions and candid responses were found important and for benevolence trust, actions and attitudes emerged as key factors (Dowell, Heffernan, \& Morrison, 2013). 


\section{Conclusions}

Property has always been a people profession, where success is predicated on building long-term relationships, trust and assurance. However, the relationship between landlord and tenant has not necessarily reflected this prevailing culture. Trust occurs at several levels. At the micro level, individuals and organisations can build trust through regular interaction, as described above.

However, in the absence of individual interaction, for example where an owner and customer might come together for the first time, institutional trust in the macro level can be very important. Taking Giddens' (1984) definition of institutions (as structural arrangements represented by rules of behaviour to which individual and collective action is oriented), the arrangement of the real estate investment market, in terms of landlord and tenant legislation, codes of practice, education and certification of members of the property profession, and the norms, structures and procedures of the real estate industry as a whole, will all influence the extent to which customers place trust in owners. Hence, the current practices employed in the leasing process itself, and the terms of the lease, are significant components of the 'Assurance' construct. In the increasingly global marketplace, corporate property managers' confidence in the institutional arrangements for both real estate and business generally of particular countries (the macro level) will influence their choice of location. At specific locations (the micro level) the individual owner's approach to business, norms, structures and procedures will contribute to any assessment of their trustworthiness and customer focus (Palm, 2011; Real Service \& EPRA, 2012). In this respect, property owners cannot afford to act in isolation and with antipathy toward development of the real estate industry as a whole. Satisfaction with legal processes appears low amongst occupiers, and this analysis indicates that improving or streamlining these processes has the scope to improve occupiers' perception of receiving value for money, and hence their overall satisfaction. The industry's move towards greater flexibility, shorter leases, flexible use of space, break clauses, rent-free periods, and the option to pay monthly rather than quarterly should continue to help build institutional trust. However, property owners need to continue to engage in debate about the appropriateness of changes to institutional arrangements and to work with corporate occupiers to seek continual improvement to the market. Low satisfaction with legal costs suggest that there is still work for the industry to undertake as a whole in continuing to drive down the transaction costs of property leasing.

\section{References}

Appel-Meulenbroek, R. (2008). Managing "keep" factors of office tenants to raise satisfaction and loyalty. Property Management, 26(1), 43-55.

Bachmann, R., \& Inkpen, A. C. (2011). Understanding Institutional-based Trust Building Processes in Interorganizational Relationships. Organization Studies, 32(2), 281-301.

Baharum, Z. A., Nawawi, A. H., \& Saat, Z. M. (2009). Assessment of Property Management Service Quality of Purpose Built Office Buildings. International Business Research, 2(1), 162-174.

BOMA, \& Kingsley Associates. (2013). BOMA 2013 Global Tenant Survey. Retrieved from http://www.wm.com/enterprise/boma/BOMA Global Tenant Study Executive Summary.pdf 
British Council for Offices, \& KingsleyLipseyMorgan. (2002). The Service Challenge: How well is the UK Office Industry Serving its Customers? London.

British Council for Offices, \& RealService Ltd. (2015). Building Performance: Rethinking the relationship between owners, managers and occupiers. London. doi:10.1037/0011686

Carifio, J., \& Perla, R. J. (2007). Ten Common Misunderstandings, Misconceptions, Persistent Myths and Urban Legends about Likert Scales and Likert Response Formats and their Antidotes. Journal of Social Sciences, $3(3), 206-216$

CBRE. (2015). Only one-in-ten companies relocate upon lease expiry. Property Magazine International. Retrieved August 7, 2015, from https://www.property-magazine.eu/only-one-in-ten-companies-relocateupon-lease-expiry-33575.html

Chin, L., \& Poh, L. K. (1999). Implementing quality in property management - The case of Singapore. Property Management, 17(4), 310-320.

Coenen, C., Alexander, K., \& Kok, H. (2012). FM as a Value Network: Exploring Relationships amongst Key FM Stakeholders. In P. A. Jensen, T. J. M. Van Der Voordt, \& C. Coenen (Eds.), THE ADDED VALUE OF FACILITIES MANAGEMENT CONCEPTS, FINDINGS AND PERSPECTIVES. Lyngby: Polyteknisk Forlag.

Cohen, J. (1988). Statistical Power Analysis for the Behavioral Sciences. (2nd, Ed.). Hillsdale, New Jersey: Lawrence Erlbaum Associates.

Cronin Jr, J. J., \& Taylor, S. A. (1992). Measuring Service Quality: A Re-examination and Extension. Journal of Marketing, 56(3), 55-68.

Crosby, N., Hughes, C., \& Murdoch, S. (2006). Flexible Property Leasing and the Small Business Tenant. Journal of Property Research, 23(2), 163-188.

Darby, M. R., \& Karni, E. (1973). Free Competition and the Optimal Amount of Fraud. Journal of Law and Economics, 16(April), 67-86.

Dowell, D., Heffernan, T., \& Morrison, M. (2013). Trust formation at the growth stage of a business- to- business relationship: A qualitative investigation. Qualitative Market Research: An International Journal, 16(4), 436-451.

Edington, G. (1997). Property Management: A Customer Focused Approach. Basingstoke: Macmillan.

Freethy, L., Morgan, H., \& Sanderson, D. C. (2011). Service Charge Code Compliance Index. RSBPG Blog. Retrieved December 16, 2012, from http://blog.real-service.co.uk/service-charge-comliance-indexresults-2011/

Frodsham, M. (2010). Strutt \& Parker / IPD Lease Events Review. In Strutt \& Parker / IPD Lease Events Review.

Gee, R., Coates, G., \& Nicholson, M. (2008). Understanding and profitably managing customer loyalty. Marketing Intelligence \& Planning, 26(4), 359-374. doi:10.1108/02634500810879278

Gibson, V. A., Hedley, C., Proctor, A., \& Fennell, B. (2000). Evaluating Office Space Needs \& Choices, IPD Occupiers. London. Retrieved from http://corporateservicedoffices.com/PDFDocuments/EvaluatingOfficeSpaceNeedsChoices.pdf

Giddens, A. (1984). The Constitution of Society, outline of the theory of structuration. Cambridge: Polity Press.

Grönroos, C. (1978). A service-oriented approach to marketing of services. European Journal of Marketing, $12(8), 588-601$.

Grönroos, C. (1982). Strategic Management and Marketing in the Service Sector. Swedish School of Economics and Business Administration.

Grönroos, C. (1990). Marketing Redefined. Management Decision, 28(8), 5-9. 
Gummesson, E. (2002a). Relationship Marketing in the New Economy. Journal of Relationship Marketing, 1(1), 37-57. doi:10.1300/J366v01n01_04

Gummesson, E. (2002b). Total Relationship Marketing. Oxford: Butterworth Heinemann / Chartered Institute of Marketing.

GVA, Property Industry Alliance, \& Corenet Global. (2011). Occupier Satisfaction Survey. Retrieved from http://www.occupiersatisfaction.org.uk/pdf/20110ccupierSatisfactionBulletin.pdf

Hair, J. F., Hult, G. T. M., Ringle, C. M., \& Sarstedt, M. (2014). A Primer on Partial Least Squares Structural Equation Modeling (PLS-SEM). Thousand Oaks, CA: SAGE Publications.

Hair, J. F., Ringle, C. M., \& Sarstedt, M. (2011). PLS-SEM: Indeed a Silver Bullet. Journal of Marketing Theory and Practice, 19(139-151)

Halvitigala, D., Murphy, L., \& Levy, D. S. (2011). The Impacts of Commercial Lease Structures on Landlord and Tenant Behaviours and Experiences. Pacific Rim Property Research Journal, 17(4), 560-583.

Heskett, J. ., Sasser, W. ., \& Schlesinger, L. A. (1997). The Service Profit Chain: How Leading Companies Link Profit and Growth to Loyalty, Satisfaction, and Value. Free Press, New York.

IPD, Cfi-group, \& RICS. (2005). RICS Tenant Satisfaction Index.

IPD Occupiers. (2013). Global Estate Measurement Code for Occupiers. Retrieved from http://www.ipd.com/resources/protected/IPD GEMCode-2013.pdf

IPD, \& Strutt \& Parker. (2012). UK Lease Events Review 2012.

IPD, Strutt \& Parker, \& BPF. (2013). IPD Lease Events Report 2013. Retrieved from http://www.bpf.org.uk/en/files/bpf_documents/commercial/IPD-MSCI-LeaseEventsReport-_FINAL.pdf

Johnson, L. L., Dotson, M. J., \& Dunlap, B. J. (1988). Service Quality Determinants and Effectiveness in the Real Estate Brokerage Industry. Journal of Real Estate Research, 3(2), 21-36.

Jylha, T., \& Junnila, S. (2014). The state of value creation in the real-estate sector - lessons from lean thinking. Property Management, 32(1), 28-47.

Kano, N., Nobuhiku, S., Fumio, T., \& Shinichi, T. (1984). Attractive quality and must-be quality. Journal of the Japanese Society for Quality Control, (April).

Keiningham, T. L., Goddard, M. K. M., Vavra, T. G., \& Iaci, A. J. (1999). Customer Delight and the Bottom Line. Marketing Management, 8(3), 57-63.

Keiningham, T. L., Perkins-Munn, T., \& Evans, H. (2003). The Impact of Customer Satisfaction on Share of Wallet in a Business-to-Business Environment. Journal of Service Research, 6(1), 37-49.

KingsleyLipseyMorgan, \& IPD Occupiers. (2007). Occupier Satisfaction Index. London.

KingsleyLipseyMorgan, \& IPD Occupiers. (2008). Occupier Satisfaction Index. London.

Levy, D. S., \& Lee, C. K. C. (2009). Switching behaviour in property related professional services. Journal of Property Research, 26(1), 87-103.

Martilla, J. ., \& James, J. . (1977). Importance-Performance Analysis. Journal of Marketing, 41(1).

Morgan, H. (n.d.). RealService Best Practice Group. Retrieved September 1, 2013, from http://www.realservice.co.uk/services/best-practice/realservice-best-practice-group/

Nelson, P. (1974). Advertising as Information. Journal of Political Economy, 82(July / Aug), 729-754.

Nelson, S. L., \& Nelson, T. R. (1995). RESERV: An Instrument for Measuring Real Estate Brokerage Service Quality. Journal of Real Estate Research, 10(1), 99-113. 
Noor, M. N. M., \& Pitt, M. (2009). A discussion of UK commercial property service charges. Journal of Retail and Leisure Property, 8(2), 119-138. doi:10.1057/rlp.2009.4

Noor, M. N. M., Pitt, M., Hunter, G., \& Tucker, M. (2010). Compliance of RICS code of practice for commercial service charges. Journal of Corporate Real Estate, 12(2), 135-144. doi:10.1108/14630011011049568

Palm, P. (2011). Customer orientation in real-estate companies: The espoused values of customer relations. Property Management, 29(2), 130-145. doi:10.1108/02637471111122435

Parasuraman, A., Zeithaml, V. A., \& Berry, L. L. (1985). A Conceptual Model of Service Quality and Its Implications for Future Research. Journal of Marketing, 49(4), 41-50. doi:10.2307/1251430

Parasuraman, A., Zeithaml, V. A., \& Berry, L. L. (1988). SERVQUAL: A Multiple-Item Scale for Measuring Consumer Perceptions of Service Quality. Journal of Retailing, 64(1), 12-40.

Property Industry Alliance, \& Corenet Global. (2010). Occupier Satisfaction Survey 2010.

Property Industry Alliance, \& GVA. (2012). Occupier Satisfaction Index 2012. Retrieved from http://www.occupiersatisfaction.org.uk/

Real Service, \& EPRA. (2012). European Listed Property Companies: Progress towards Customer Focus. Retrieved from www.real-service.co.uk

RealService Ltd. (2010). Best Practice Index Framework.

RealService Ltd, \& IPD. (2009). Occupier Satisfaction Index. London.

Reichheld, F. F. (2003). The One Number You Need to Grow. Harvard Business Review, (December), 46-54.

Reichheld, F. F., \& Teal, T. (1996). The Loyalty Effect: The Hidden Force Behind Growth, Profits, and Lasting Value. Harvard Business School Press.

Roberts, J., Merrilees, B., Herington, C., \& Miller, D. (2010). Building retail tenant trust: Neighbourhood versus regional shopping centres. International Journal of Retail and Distribution Management, 38(8), 597-612.

Ronco, W. (1998). Improving partnering results : Managing Alliances for Optimum Outcomes. Journal of Corporate Real Estate, 1(1), 29-34.

Rust, R. T., Zahorik, A. J., \& Keiningham, T. L. (1994). Return on Quality (ROQ): Measuring the Financial Impact of Your Company's Quest for Quality. Irwin Professional Publishing.

Sanderson, D. C. (2012). Olympic Volunteers and Customer Service. Real-Service News and BlogService. Retrieved from http://blog.real-service.co.uk/olympic-volunteers-and-customer-service-a-personalperspective/

Sanderson, D. C. (2015). The Tenant as Customer: Does Good Service Enhance the Financial Performance of Commercial Real Estate. University of Reading.

Sanderson, D. C., \& Edwards, V. M. (2014). What Tenants Want: UK Occupiers' requirements when renting commercial property and strategic implications for landlords. In American Real Estate Society Conference. San Diego.

Schneider, B., \& White, S. S. (2004). Service Quality Research Perspectives. (Foundation for Organisational Science, Ed.). Thousand Oaks, CA: SAGE Publications.

Seiler, V. L., \& Reisenwitz, T. H. (2010). A Review of Service Quality Research in Real Estate. Journal of Real Estate Literature, 18(2), 225-238.

Seiler, V. L., Seiler, M. J., Arndt, A. D., Newell, G., \& Webb, J. R. (2010). Measuring Service Quality with Instrument Variation in an SEM Framework. Journal of Housing Research, 19(1), 47-63. 
Seiler, V. L., Webb, J. R., \& Whipple, T. W. (2000). Assessment of Real Estate Brokerage Service Quality with a Practising Professional's Instrument. Journal of Real Estate Research, 20(1/2), 105-117.

Silver, M. (2000). REITs must serve true client base: tenants. National Real Estate Investor, 42(4), 96.

Smith, A. (1776). An Inquiry into the Nature and Causes of the Wealth of Nations (Electronic.). An Electronic Classics Series Publication. Retrieved from http://www2.hn.psu.edu/faculty/jmanis/adam-smith/WealthNations.pdf

Söderlund, M., \& Vilgon, M. (1999). Customer Satisfaction and Links to Customer Profitability: An Empirical Examination of the Association Between Attitudes and Behavior: SSE/EFI Working Paper Series in Business Administration.

Tucker, M., \& Pitt, M. (2010). Improving service provision through better management and measurement of customer satisfaction in facilities management. Journal of Corporate Real Estate, 12(4), 220-233. doi: $10.1108 / 14630011011094667$

UK Occupier Satisfaction Index 2007-2012. (2012). Retrieved November 16, 2012, from http://www.occupiersatisfaction.org.uk/

Valley, M. (2001). Take care of your best assets-your tenants. National Real Estate Investor, 43(13), 23 - 25.

Van Ree, H. J. (2009). Service Quality Indicators For Business Support Services. University College, London.

Venkateswaran, R. (2003). A customer satisfied is not a customer retained. Indian Institute of Management at Bangalore Management Review, (Sept), 120-123.

Westbrook, K. W., \& Peterson, R. M. (1998). Business-to-business selling determinants of quality. Industrial Marketing Management, 27(1), 51-62.

Williamson, O. E. (2002). The Theory of the Firm as Governance Structure: From Choice to Contract. The Journal of Economic Perspectives, 16(3), 171 - 195.

Wilson, C., Leckman, J., Cappucino, K., \& Pullen, W. (2001). Towards customer delight: Added value in public sector corporate real estate. Journal of Corporate Real Estate, 3(3), 215-221.

Worthington, R. (2015, February). Financial Comment. Estates Gazette No. 816, 05. Retrieved from http://www.estatesgazette.com

Yang, C.-C. (2005). The Refined Kano's Model and its Application. Total Quality Management, 16(10), 11271137.

Zeithaml, V. A., Berry, L. L., \& Parasuraman, A. (1990). Delivering Quality Service: balancing customer perceptions and expectations. New York: The Free Press; Simon \& Schuster.

Zeithaml, V. A., Berry, L., \& Parasuraman, A. (1996). Behavioral Consequences of Service Quality. Journal of Marketing, 60(2), 31-46. 